\title{
TRANSIENT SIMULATION STUDY OF FLOOR HEATING SYSTEMS
}

\author{
LUCIE HORKA*, JIRI HIRS \\ Faculty of Civil Engineering, Brno University of Technology, Veveri 331/95, 60200 Brno, Czech Republic \\ *E-mail: horka.1@fce.vutbr.cz
}

\begin{abstract}
This case study is aimed at transient simulation of floor heating systems. There is comparison of surface floor temperatures and heat fluxes changes of different systems over time. The first studied system is a dry floor heating system which consists of system boards made from insulation material, spreader plates, and it is covered by cement fiber boards. The second examined system is heavy wet concrete floor heating system whose heating power is set identically as heating power of dry floor heating system. Mean temperature of heating water is investigated. All simulations, both time steady-state and transient, are performed in software CalA. Reduction of duration and computational performance of simulation is achieved by creation of a surrogate model. The surrogate model evinces identical surface temperatures and heat fluxes. Total number of computational grid is reduced and therefore lower number of equations is solved. Results show that dry floor heating system has faster response than concreate floor heating system. It is caused by lower weight and lower thermal capacity of this system.
\end{abstract}

Keywords: floor heating, software CalA, numerical simulation, surrogate model, steady-state simulation, transient simulation

\section{Introduction}

Three different floor heating systems are examined. The first studied system (Model 1) is dry floor heating system which consists of system boards made from insulation material, spreader plates, and it is covered by cement fiber boards. The second examined system (Model 2) is wet anhydrite floor heating system and the third one (Model 3) is heavy wet concreate floor heating system. Dry floor heating system is mostly used for floor reconstructions and for a floor heating system for wooden houses. This solution is used in these light-weight buildings because cement screed or anhydrite layer are wet processes and increase the load of celling construction.

A lot of publications are aimed at problematics of floor heating systems [1] also examining different compositions and constructions. Simulations and measurements are most frequently methods to study temperature field or heat power of floor heating [2-4]. Dry floor heating systems are very often used in the United States of America where many different patents of these systems are held [5-6]. It is possible to use numerical simulation to solve both steady and transient states of thermal activated constructions [7-9].

\section{Materials and calculation methods}

\subsection{Calculation method}

The simulations were carried out in software CalA, which is developed at Brno University of Technology. It is based on numerical solution of 2D heat conduction Eq. (1) by finite volume method, see [10].

$$
\frac{\partial}{\partial x}\left(\lambda \frac{\partial T}{\partial x}\right)+\frac{\partial}{\partial y}\left(\lambda \frac{\partial T}{\partial y}\right)+\dot{Q}=\rho c \frac{\partial T}{\partial \tau}
$$

where $T\left[{ }^{\circ} \mathrm{C}\right]$ is temperature, $\lambda\left[\mathrm{W} \cdot \mathrm{m}^{-1} \mathrm{~K}^{-1}\right]$ thermal conductivity, $\rho\left[\mathrm{kg} \cdot \mathrm{m}^{-3}\right]$ density, $c\left[\mathrm{~J} \cdot \mathrm{kg}^{-1} \mathrm{~K}^{-1}\right]$ specific thermal capacity, $\tau$ [s] time, $\dot{Q}[\mathrm{~W}]$ volumetric heat source.

The detailed calculation of linear thermal transmittance in case of contact external peripheral wall and plastic window frame [11] or the impact of freezer room operation on changes of temperature field in subsoil within both steady-state and transient boundary conditions [12] were performed in software CalA. The comparison of results of software CalA and ANSYS Fluent is also performed [13].

This is an open-access article distributed under the terms of the Creative Commons Attribution-NonCommercial 4.0 International License (https://creativecommons.org/licenses/by-nc/4.0/), which permits unrestricted use, distribution, and reproduction in any medium for non-commercial purposes, provided the original author and source are credited, a link to the CC License is provided, and changes - if any - are indicated. 


\subsection{Geometry}

The calculation models represent typical section of heating systems and the adjacent floor construction. Axes of symmetry are used for creation of these models. The width of models is determined as a half of axial distance of heating pipes. Axial distance of heating pipes is $150 \mathrm{~mm}$ therefore the width of model is 75 mm, see Fig. 1.

\subsection{Material characteristics}

Material characteristics of used materials are listed in Table 1. Compositions of examined floor heating systems and thickness of individual layers are shown in Fig. 1.

\subsection{Boundary conditions}

Model boundary conditions are set both steady-state and transient. The boundary condition I - Indoor cli-

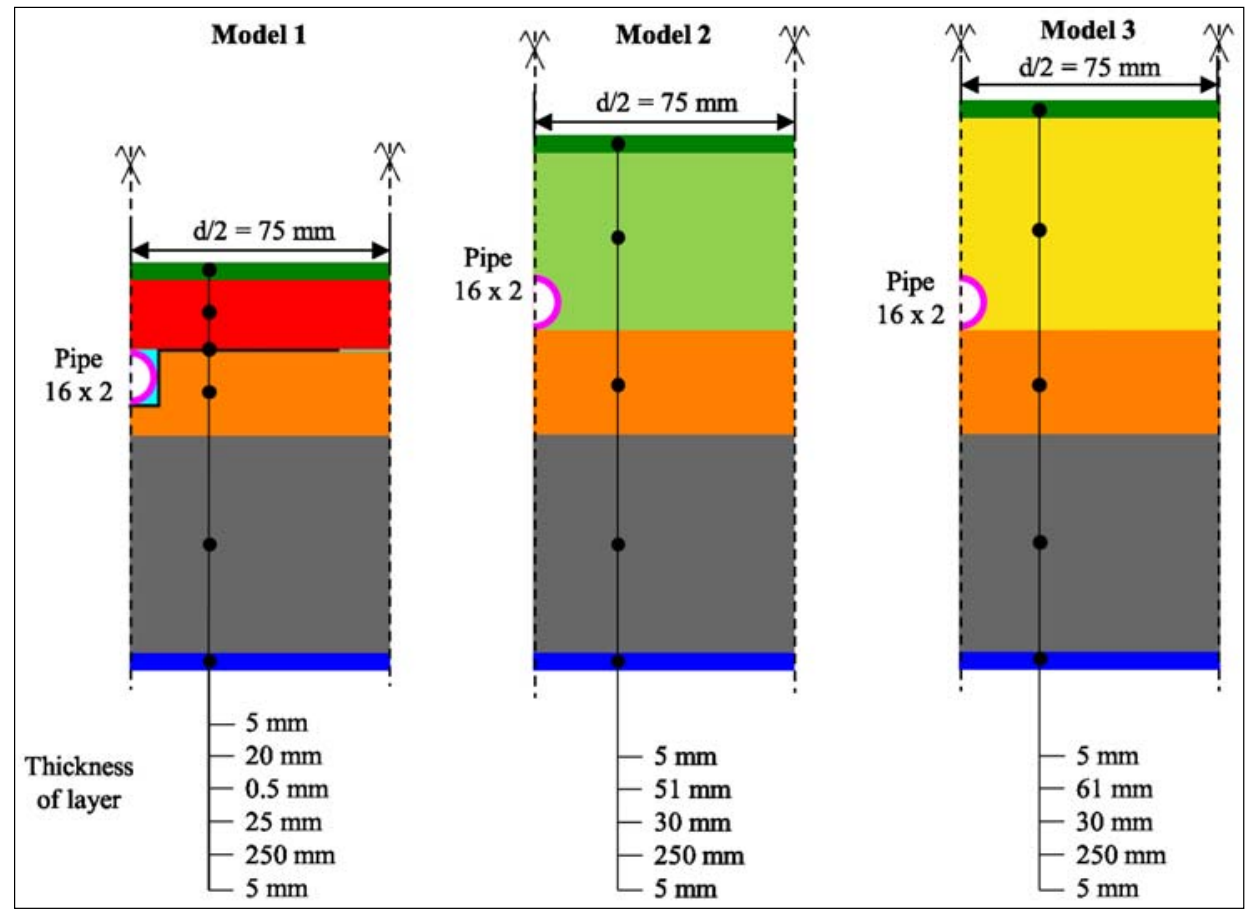

Fig. 1. Compositions of examined floor heating systems and thickness of layers

Table 1. Material characteristics

\begin{tabular}{lccc}
\hline Material & $\begin{array}{c}\text { Thermal conductivity } \\
\lambda\left[\mathrm{W} \cdot \mathrm{m}^{-1} \mathrm{~K}^{-1}\right]\end{array}$ & $\begin{array}{c}\text { Density } \\
\rho\left[\mathrm{kg} \cdot \mathrm{m}^{-3}\right]\end{array}$ & $\begin{array}{c}\text { Thermal capacity } \\
c\left[\mathrm{~J} \cdot \mathrm{kg}^{-1} \mathrm{~K}^{-1}\right]\end{array}$ \\
\hline PVC & 0.16 & 1400 & 1100 \\
Fermacell boards & 0.35 & 1150 & 1100 \\
Extruded polystyrene & 0.034 & 30 & 2060 \\
Reinforced concrete & 1.43 & 2300 & 1020 \\
Plaster & 0.88 & 2000 & 790 \\
Polyethylene & 0.35 & 930 & 1470 \\
Air & 0.07 & 1 & 1010 \\
Spreader plate (steel) & 20 & 7850 & 440 \\
Cement screed & 1.1 & 2100 & 1570 \\
\hline Anhydrite & 1.8 & 2100 & 1550 \\
\hline
\end{tabular}




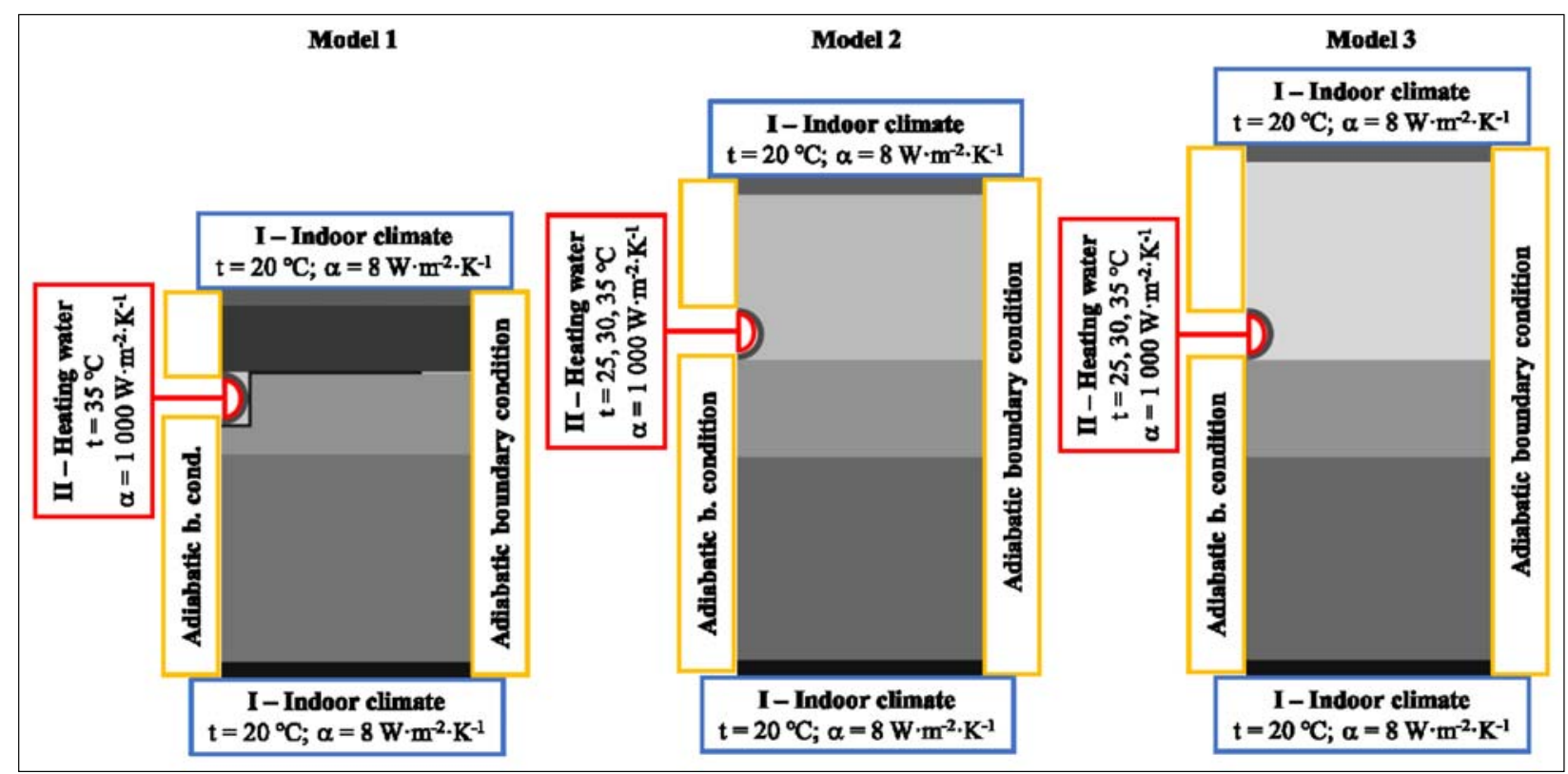

Fig. 2. Boundary conditions of examined models

mate is Newton boundary condition and is same above and below the examined construction. The temperature of indoor climate is designed indoor air temperature during the winter season and is unchangeable. The boundary condition II - Heating water is also Newton boundary condition. The temperature of heating water presents average of inlet and outlet heating water. Transient models simulate starting-up the floor heating systems. The boundary condition of symmetry axes is the adiabatic boundary condition. Parameters of boundary conditions are shown in Fig. 2.
Heating water temperature of Models 2 and 3 is parametrically changed so that useful heat flux of both models is same as useful heat flux of Model 1.

\subsection{Simplified models}

Geometry of simplified models of examined floor heating systems is adjusted. Thickness of concreate layer is reduced to one quarter of the original thickness, see Fig. 3. Number of solved equations are reduced 2.6 times (from 1460526 to 560526 equations).

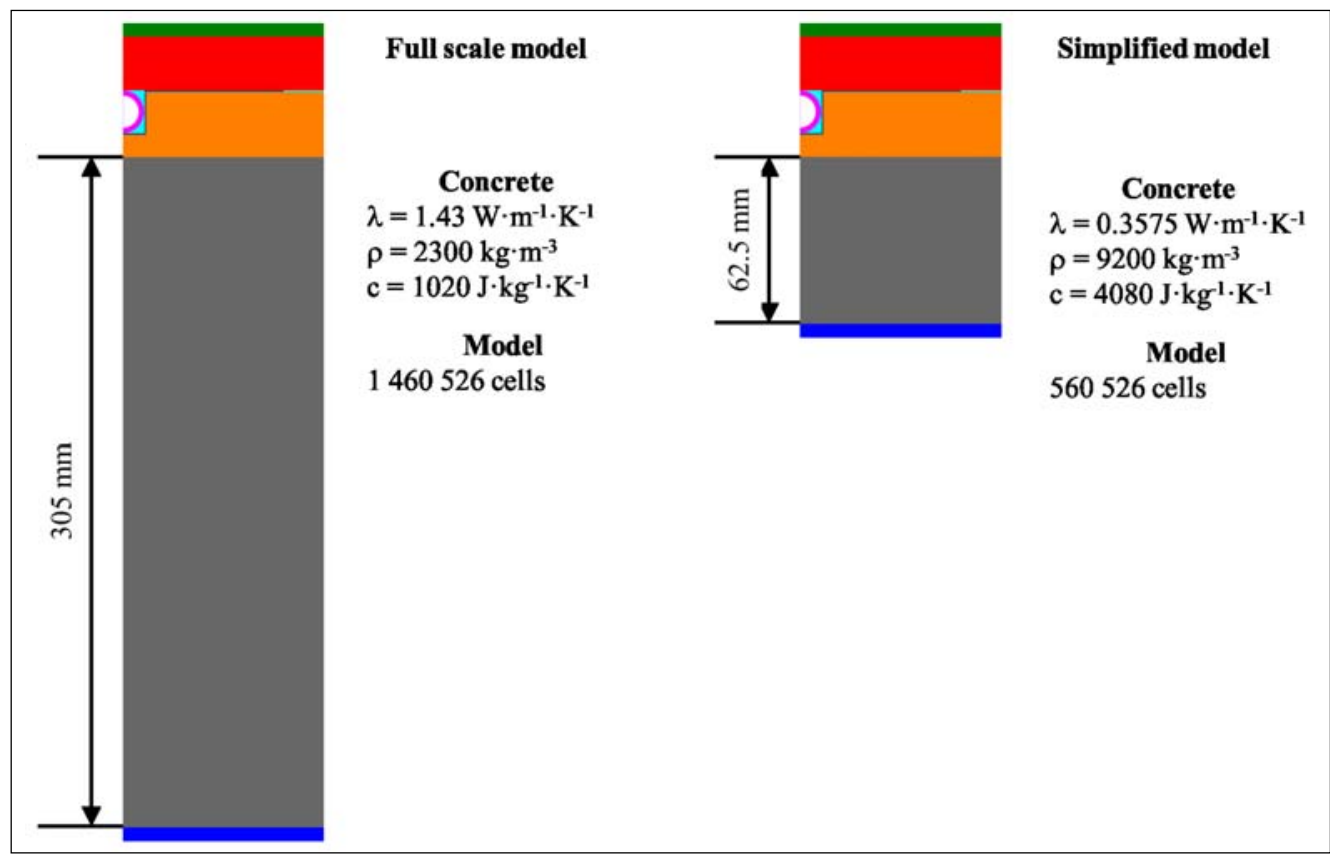

Fig. 3. Comparison of full scale model and simplified model 
Material characteristics of concrete are transformed so that the thermal conductivity and thermal accumulation of concrete layer are identical in both models, see Fig. 2. The reason is that there is no possibility to transform discretization of part of model mesh in software CalA.

\section{Results}

\subsection{Heating water temperatures}

Results of steady-state parametrical simulation of Model 2 and Model 3 are listed below in Table 2 .
Corresponding heating water temperatures are determined by using the functional approximation, see Figs 4 and 5. The resulting heating water temperatures for all models are listed below in Table 3, these temperatures are used in the following transient simulations.

\subsection{Comparison of full scale model and simplified model}

Floor and ceiling (bottom of the model) surface temperatures of dry floor heating system of both full scale and simplified models are compared in Figs 6 and 7.

Table 2. Results of parametrical simulation

\begin{tabular}{|c|c|c|c|c|c|}
\hline \multicolumn{3}{|c|}{ Anhydrite floor heating system } & \multicolumn{3}{|c|}{ Cement screed floor heating system } \\
\hline $\begin{array}{l}\text { Temperature of } \\
\text { heating water }\end{array}$ & $\begin{array}{l}\text { Average of floor } \\
\text { surface temper- } \\
\text { ature }\end{array}$ & $\begin{array}{l}\text { Average of useful } \\
\text { heat flux density }\end{array}$ & $\begin{array}{l}\text { Temperature of } \\
\text { heating water }\end{array}$ & $\begin{array}{l}\text { Average of floor } \\
\text { surface temper- } \\
\text { ature }\end{array}$ & $\begin{array}{l}\text { Average of useful } \\
\text { heat flux density }\end{array}$ \\
\hline$\left[{ }^{\circ} \mathrm{C}\right]$ & {$\left[{ }^{\circ} \mathrm{C}\right]$} & {$\left[\mathrm{W} \cdot \mathrm{m}^{-2}\right]$} & {$\left[{ }^{\circ} \mathrm{C}\right]$} & {$\left[{ }^{\circ} \mathrm{C}\right]$} & {$\left[\mathrm{W} \cdot \mathrm{m}^{-2}\right]$} \\
\hline 25 & 22.63 & 21.00 & 25 & 22.24 & 17.90 \\
\hline 30 & 25.25 & 42.01 & 30 & 24.48 & 35.80 \\
\hline 35 & 27.87 & 63.00 & 35 & 26.73 & 53.87 \\
\hline
\end{tabular}

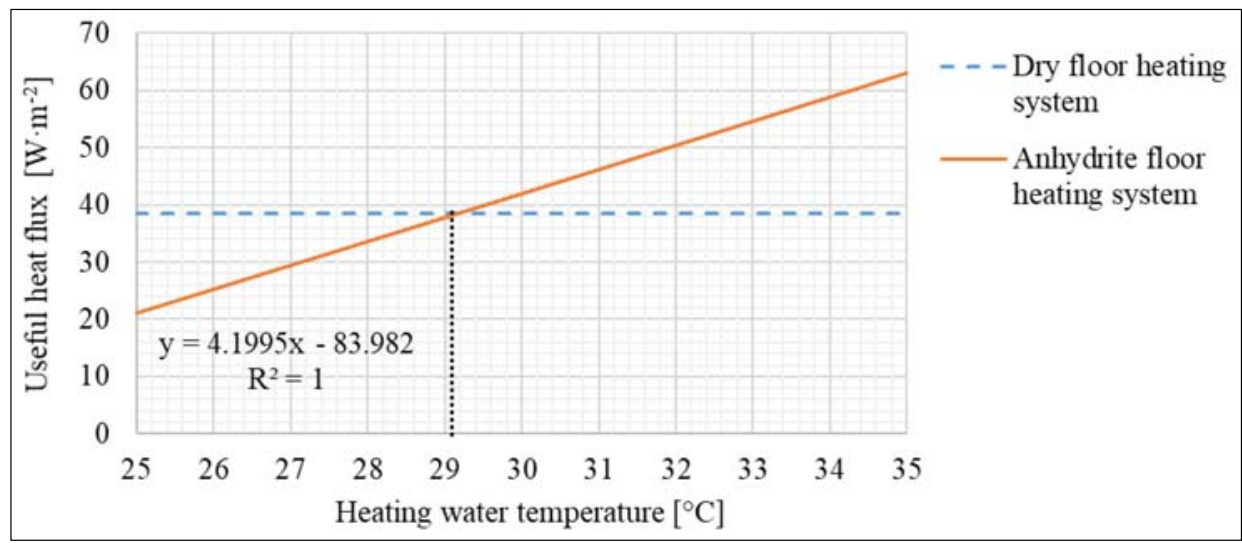

Fig. 4. Investigation of heating water temperature of anhydrite floor heating system

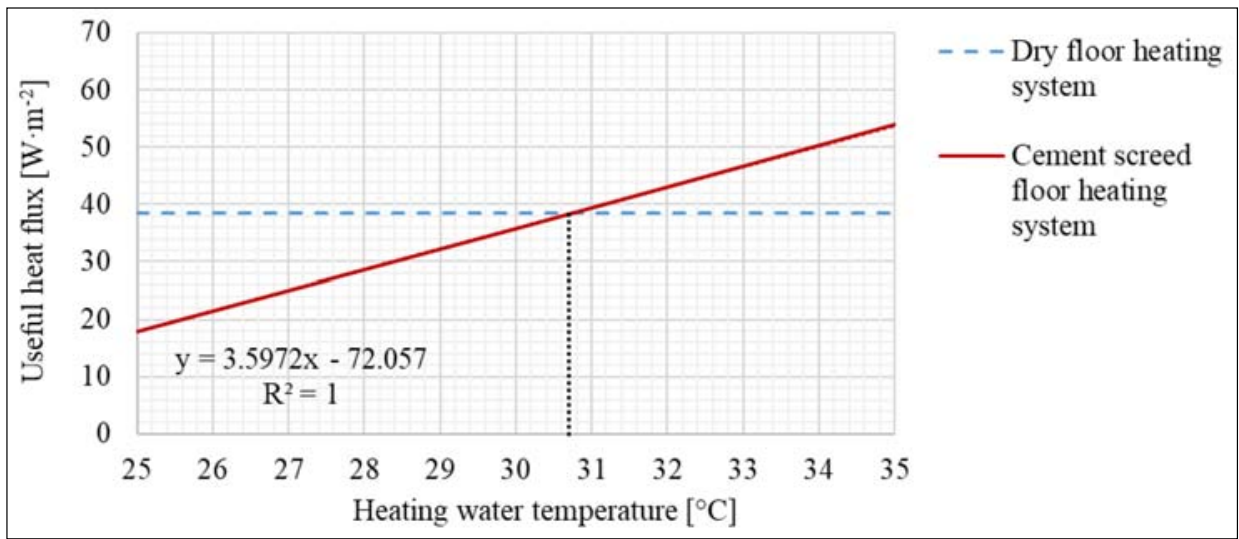

Fig. 5. Investigation of heating water temperature of cement screed floor heating system 
Table 3. Heating water temperatures

\begin{tabular}{llccc}
\hline \multirow{2}{*}{ Model } & & $\begin{array}{c}\text { Temperature of } \\
\text { heating water }\end{array}$ & $\begin{array}{c}\text { Average of floor } \\
\text { surface temperature }\end{array}$ & $\begin{array}{c}\text { Average of useful } \\
\text { heat flux density }\end{array}$ \\
\cline { 3 - 5 } & Dry floor heating system & {$\left[{ }^{\circ} \mathrm{C}\right]$} & {$\left[{ }^{\circ} \mathrm{C}\right]$} & {$\left[\mathrm{W} \cdot \mathrm{m}^{-2}\right]$} \\
\hline Model 1 & $\mathbf{3 5}$ & 24.803 & 38.423 \\
Model 2 & Anhydrite floor heating system & $\mathbf{2 9 . 1 5}$ & 24.804 & 38.433 \\
Model 3 & Cement screed floor heating system & $\mathbf{3 0 . 7 1}$ & 24.802 & 38.413 \\
\hline
\end{tabular}

Average value of surface temperatures and heat fluxes including differences between models are listed below in Tables 4 and 6. Upper parts of temperature fields of models are shown in Fig. 8.

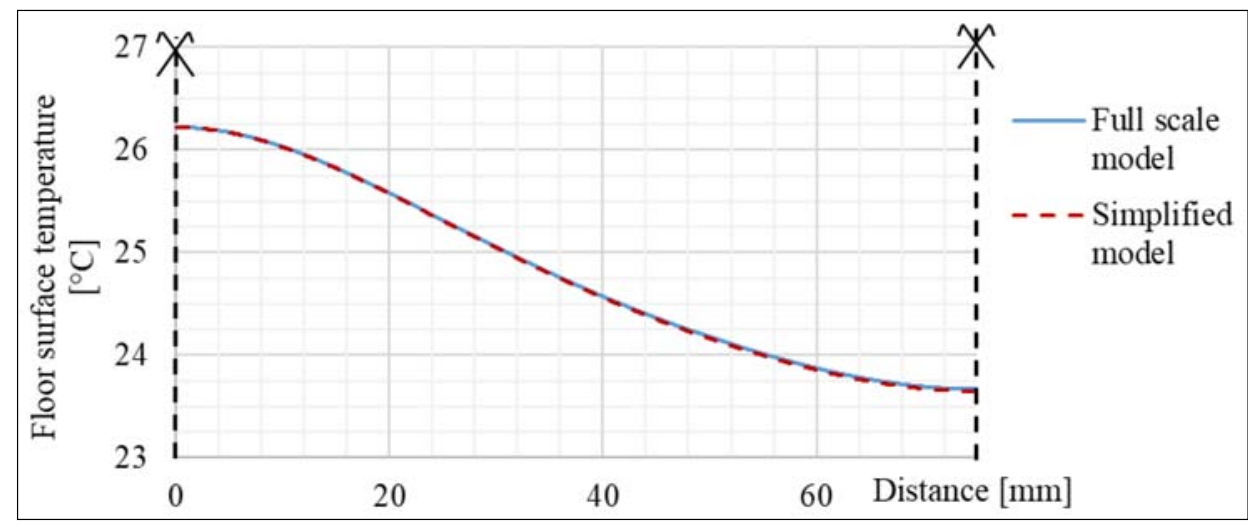

Fig. 6. Comparison of floor surface temperature of full scale model and simplified model

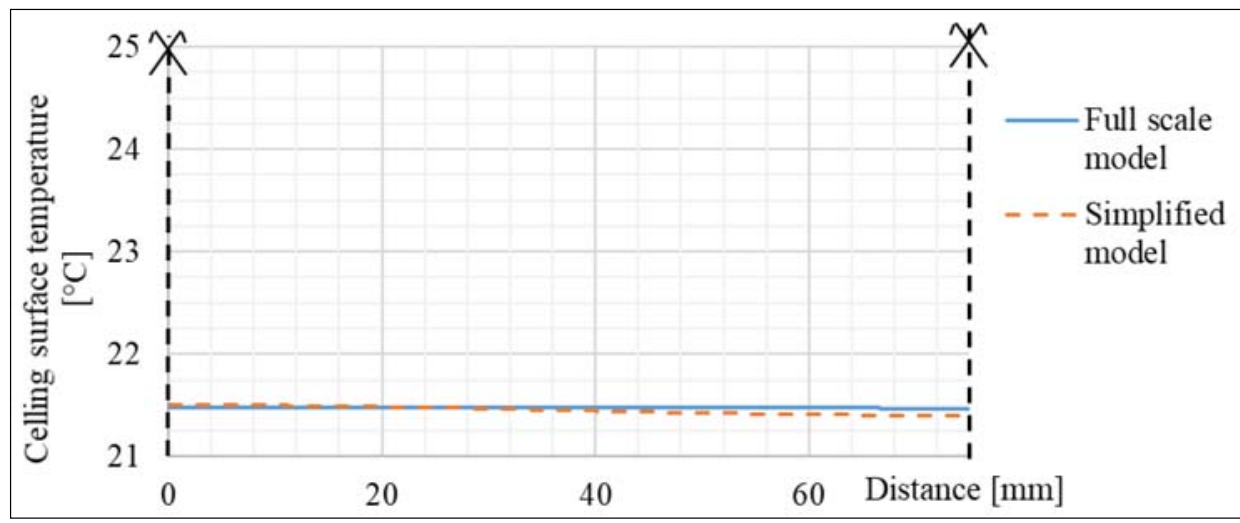

Fig. 7. Comparison of celling surface temperature of full scale model and simplified model

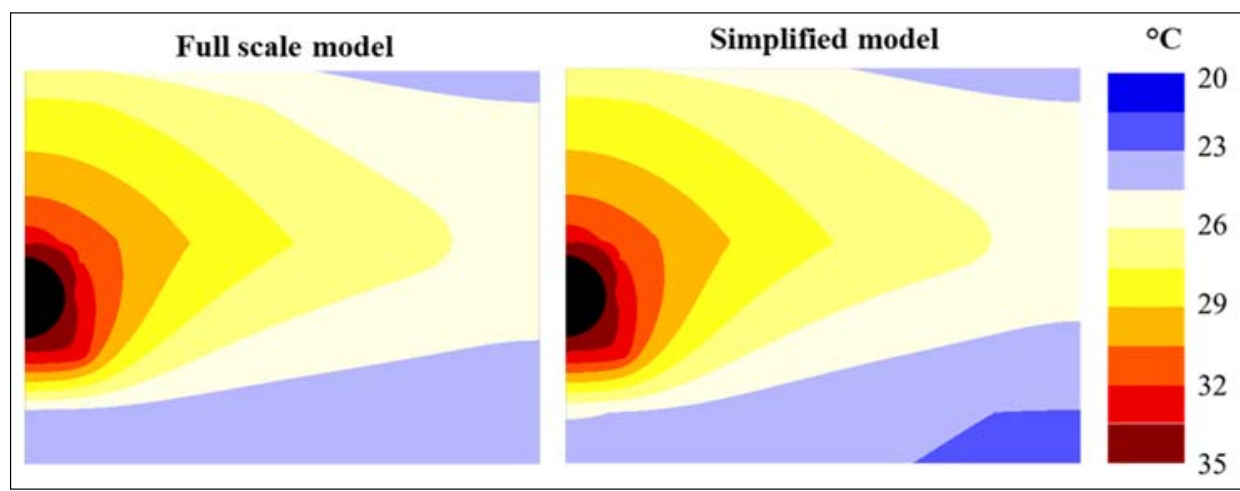

Fig. 8. Comparison of temperature field of full scale model and simplified model 
Table 4. Average surface temperature

\begin{tabular}{lcccc}
\hline & Full scale model & Simplified model & Difference & Difference \\
\cline { 2 - 5 } & {$\left[{ }^{\circ} \mathrm{C}\right]$} & {$\left[{ }^{\circ} \mathrm{C}\right]$} & {$\left[{ }^{\circ} \mathrm{C}\right]$} & {$[\%]$} \\
\hline Floor & 24.814 & 24.803 & 0.011 & 0.04 \\
Celling & 21.476 & 21.452 & 0.024 & 0.11 \\
\hline
\end{tabular}

Table 5. Average heat flux

\begin{tabular}{lcccc}
\hline & Full scale model & Simplified model & Difference & Difference \\
\cline { 2 - 5 } & {$\left[\mathrm{W} \cdot \mathrm{m}^{-2}\right]$} & {$\left[\mathrm{W} \cdot \mathrm{m}^{-2}\right]$} & {$\left[\mathrm{W} \cdot \mathrm{m}^{-2}\right]$} & {$[\%]$} \\
\hline Useful heat & 38.509 & 38.423 & 0.086 & 0.22 \\
Heat losses & 11.808 & 11.613 & 0.195 & 1.65 \\
\hline
\end{tabular}

\subsection{Transient simulations}

Simplified models of floor heating systems are used for transient simulations. Floor surface temperature and useful heat fluxes over time are shown in Figs 9 and 10. First time step length is 1 second, next time step is always twice of previous step. Time step length starts to be constant when it reaches 10 minutes.

\section{Discussion}

The thermal conductivity of concrete of simplified model is set as isotropic although geometry of con- crete layer is modified only in the vertical direction. The results show that this simplification has negligible impact on floor surface temperature and useful heat flux. Anisotropic thermal conductivity is also examined but it does not reach reduction of duration of simulation.

Heating water temperature of dry floor heating system is approximately $5^{\circ} \mathrm{C}$ higher than anhydrite and concrete floor heating system with identical useful heat flux. It is caused by thermal conductivity of fermacell boards located over the heating pipes. On the other hand, thickness of fermacell board layer is lower than anhydrite and cement layer. Thermal capacity of

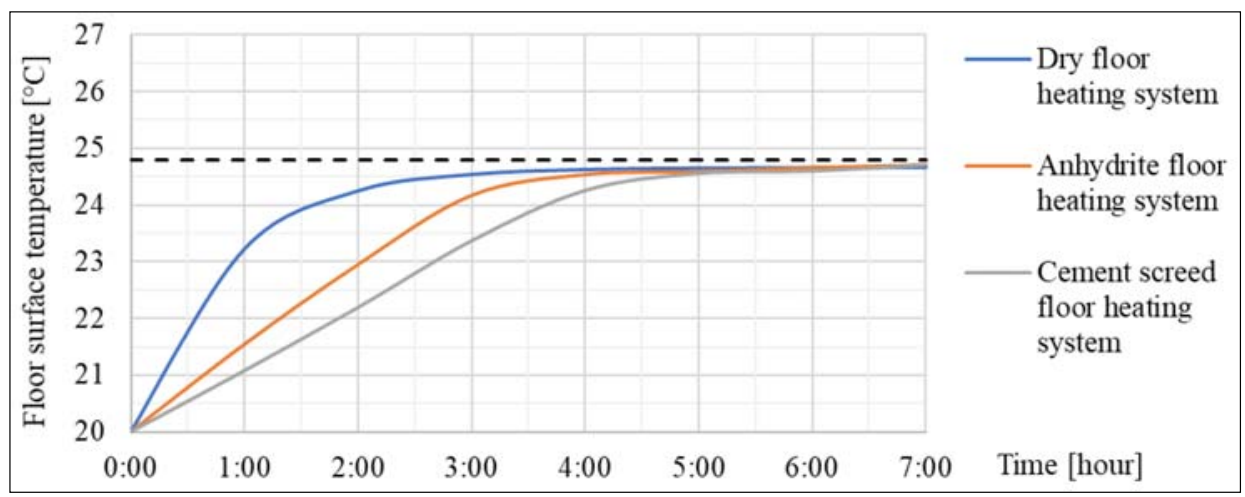

Fig. 9. Floor surface temperature over time

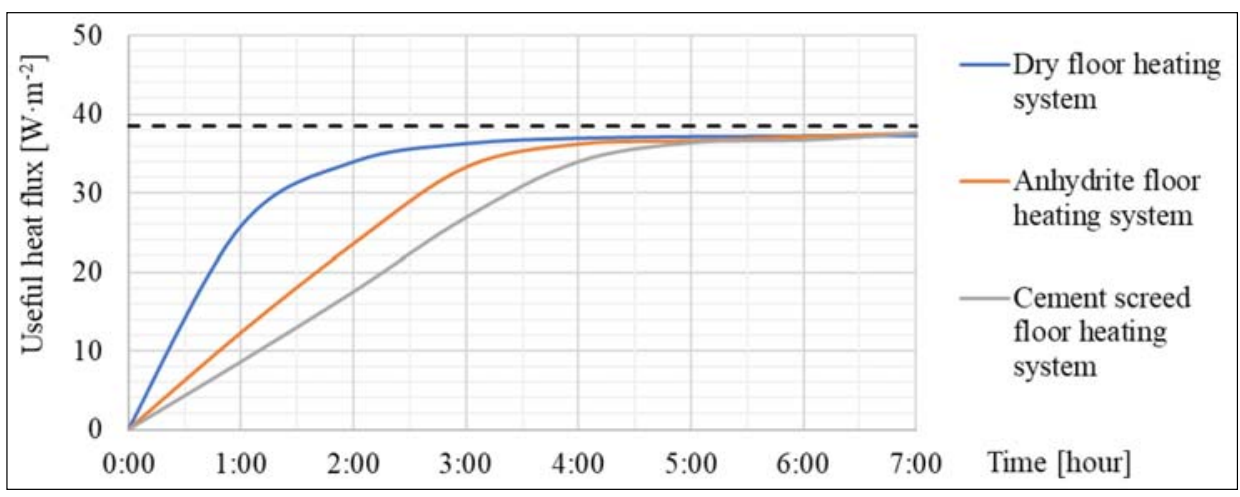

Fig. 10. Useful heat flux over time 
fermacell layer is also lower and it has impact on faster response of dry floor heating system.

\section{Conclusion}

The main goal of this study is the assessment of the use of geometric simplified models of floor heating systems and the use of these models for transient simulations. Difference of average floor surface temperature of full scale model and simplified model is lower than $0.05 \%$ and difference of average ceiling surface temperature is lower than $0.2 \%$. Difference of average heat fluxes is slightly higher because heat fluxes are calculated from temperature field. The difference of useful heat flux is lower than $0.3 \%$ and the difference of heat losses is lower than $1.7 \%$. These results show good similarity between both models. Number of solved equations is reduced 2.6 times and duration of simulation is also reduced. Results of transient simulations show that dry floor heating system has faster response than concrete floor heating system. It is caused by lower weight and lower thermal capacity of this system.

\section{Acknowledgements}

This contribution has been supported by project reg. no. LO1408 "AdMaS UP - Advanced Building Materials. Structures and Technologies" and specific research at Brno University of Technology reg. no. FAST-S-18-5217.

\section{References}

[1] Handbook (1996), ASHRAE. HVAC systems and equipment. American Society of Heating. Refrigerating. and Air Conditioning Engineers. Atlanta, GA.
[2] Olesen B. W. (2002), Radiant floor heating in theory and practice. ASHRAE Journal, 44(7), 19.

[3] Weitzmann P., Kragh J., Roots P., Svendsen S. (2005), Modelling floor heating systems using a validated twodimensional ground-coupled numerical model. Building and Environment, 40(2), 153-163.

[4] Sattari S., Farhanieh B. (2006), A parametric study on radiant floor heating system performance. Renewable Energy, 31(10), 1617-1626.

[5] Fiedrich J. (2001), Dry installation of a radiant floor or wall hydronic heating system, metal radiating plates that attach to the edges of side-by-side boards and provide metal slots for holding hot water tubing. U.S. Patent No. $6,330,980$.

[6] Fiedrich J. (2002), Dry installation of a radiant floor or wall hydronic heating system, metal radiating sheets that attach to the rough floor or wall adapted with a metal slot for holding hot water tubing. U.S. Patent Application No. 10/234,787.

[7] Shin M. S., Rhee K. N., Ryu S. R., Yeo M. S., Kim K. W. (2015), Design of radiant floor heating panel in view of floor surface temperatures. Building and Environment, 92, 559-577.

[8] Wang D., Wu C., Liu Y., Chen P., Liu J. (2016), Experimental study on the thermal performance of an enhanced-convection overhead radiant floor heating system. Energy and Buildings, 135, 233-243.

[9] Šikula O. (2011), Počítačové modelování tepelně aktivovaných konstrukcí (in Czech). VUTIUM. Brno.

[10] Šikula O. (2009), Manuál k softwaru CalA (in Czech). Tribun EU. Brno.

[11] Plášek J., Šikula O. (2014), Transient Numerical Simulation of Linear Thermal Transmittance in Software CalA. Envibuild 2014. Trans Tech Publications. Switzerland.

[12] Horká L., Šikula O., Weyr J. (2015), Numerical Simulation of Subsoil Freezing Risk under the Freezer Room. Science and Engineering 2015. Trans Tech Publications. Płock.

[13] Šikula O., Mohelníková J., Plášek J. (2014), Thermal Analysis of Light Pipes for Insulated Flat Roofs. Energy and Buildings. Elsevier B.V. Amsterdam. 